\title{
PELATIHAN BAHASA INGGRIS PADA PEMANDU WISATA DI KOTA MANADO
}

\author{
Ignatius Javier Tuerah ${ }^{\mathbf{1}}$ ), Jeane Tuilan ${ }^{2}$ ) \\ Fakultas Bahasa dan Seni, Universitas Negeri Manado 1),2) \\ email: javierignatius@unima.ac.id 1), \\ jeanetuilan@unima.ac.id 2)
}

\begin{abstract}
The declaration of tourism program 'Visit Indonesia' and 'Pesona Indonesia' by Indonesian government was expected to increase the prosperity of Indonesian society. Manado, the capital city of North Sulawesi, is one of some Indonesian territories that support the program. As one of the most important aspects in tourism, tour guides needed to be stocked with English speaking skills. This training aimed to train and improve English skills of tour guides, and revealed that the roles such as propriety and giving information. The training was done in Manado and it was discovered that (1) the tour guides in Manado do not functioned well because of the lack of English skills, (2) the propriety in welcoming tourists need more training.
\end{abstract}

Keywords: English training, tour guides, propriety.

\section{PENDAHULUAN}

Arah perkembangan zaman yang begitu cepat akibat derasnya arus globalisasi membawa dampak positif pada perkembangan dunia pariwisata, termasuk di Indonesia. Sadar akan besarnya pengaruh positif yang dapat diterima dari dunia kepariwisataan, maka pemerintah Indonesia berupaya dengan sekuat tenaga untuk memanfaatkan segala aspek kepariwisataan. Berbekal kekayaan alam yang mumpuni, lautan yang luas dan pegunungan yang hijau dan indah, serta tersebar hampir merata di seluruh pelosok Indonesia, maka pemerintah kemudian mencanangkan program wisata unggulan seperti Visit Indonesia dan Pesona Indonesia. Program ini disosialisasikan tidak hanya di dalam negeri tapi juga di luar negeri. Di dalam negeri bermaksud agar pemerintah dan masyarakat daerah boleh mempersiapkan diri sebaik mungkin, dan di luar negeri bermaksud untuk mengundang para wisatawan untuk dapat berkunjung serta menikmati Indonesia.

Pemerintah kota Manado, sebagai salah satu daerah yang memiliki kekayaan yang cukup dalam dunia kepariwisataan, menanggapi serius akan program yang telah dicanangkan oleh pemerintah pusat. Beragam persiapan serta kegiatan lokal yang dapat mendukung dunia kepariwisataan digenjot terus menerus. Selain itu, sosialisasi terhadap masyarakat internal Manado, dilaksanakan sesering mungkin, agar masyarakat boleh mengetahui dan menyadari manfaat positif yang boleh didapat lewat dunia kepariwisataan.

Akan tetapi, satu hal penting yang tidak boleh dilewatkan dalam kepariwisataan adalah pemandu wisata. Pemandu wisata atau Pramuwisata adalah orang yang bertugas memberikan bimbingan, informasi, dan petunjuk tentang atraksi atau destinasi. Pekerjaan memandu wisatawan terkesan sebagai satu pekerjaan yang bersifat mewah dan menyenangkan dengan imbalan yang besar, padahal pramuwisata merupakan salah satu profesi yang unik, karena profesi ini membutuhkan kemampuan berbahasa asing serta dapat berinteraksi dengan wisatawan, memiliki pengetahuan luas, fleksibel, penuh pengertian dan kedewasaan berpikir serta kesehatan yang mumpun.

Pada dasarnya kemampuan ini tidak hanya didapat dari sekolah/kuliah maupun kursus, tetapi didapat dari pengalaman yang dikumpulkan sedikit demi sedikit dari mengenal 
objek wisata dan melakukan pemanduan tidak resmi. Semakin sering melakukan kegiatan ini, maka mereka akan semakin berpengalaman dan semakin mamahami seluk beluk dunia kepariwisataan. Hanya sedikit orang yang memahami bahwa pekerjaan ini juga memiliki bermacam-macam halangan/kesulitan yang mungkin terjadi dalam pelaksanaan operasionalnya. Kesulitan yang mungkin terjadi dalam kegiatan sebagai tour guide di antaranya adalah: kehilangan bagasi, pesawat yang overbook, penumpang yang mengeluh, marah, keberangkatan yang tertunda, dan sebagainya.

Karier pramuwisata dapat ditingkatkan menjadi seorang tour planner, bila mereka dapat membuka usaha layanan jasa wisata, mulai dari membuat paket tour, memasarkan dan melaksanakan operasional wisata. Pramuwisata merupakan duta wisata, bukan hanya bagi perusahaan, terlebih bagi bangsa serta mengemban citra budaya bangsa, karena mereka adalah ujung tombak dari keberhasilan promosi pariwisata. Tugas seorang pramuwisata adalah memimpin pelaksanaan suatu kegiatan kunjungan/wisata mulai dari persiapan sampai pada akhir kegiatan sesuai dengan ketentuan dalam fasilitas paket tour atau peraturan/ketentuan yang telah disepakati antara perusahaan perjalanan wisata dengan wisatawan.

Masalah masalah pokok:

a. Pengetahuan dan kemampuan berbahasa Inggris pemandu wisata sangat dibutuhkan.

b. Pelatihan peningkatan kemampuan berbahasa Inggris para tour guide/pemandu wisata sangat dibutuhkan.

Pelatihan yang dibutuhkan mencakup etika dan sopan santun menjadi tour guide/pemandu wisata dan praktek berbahasa Inggris yang sopan dan santun bagi para turis/wisatawan asing.

\section{KAJIAN LITERATUR DAN PEGEMB ANGAN HIPOTESIS \\ Target}

Target pelaksanaan pelatihan kegiatan ini adalah:

a. Mengetahui dan mampu berbahasa Inggris dengan baik bagi pemandu wisata.

b. Meningkatkan kemampuan berbahasa Inggris para tour guide/pemandu wisata.

c. Melatih etika dan sopan santan menjadi tour guide/pemandu wisata dan praktek berbahasa Inggris yang sopan dan santun bagi para turis/wisatawan asing.

\section{Luaran}

Dalam meningkatkan kemampuan berbahasa Inggris pemandu wisata di kota Manado diperoleh berbagai bentuk luaran yakni:

a. Peningkatkan wawasan dan pemahaman para pemandu wisata akan kompetensi berbahasa Inggris.

b. Peningkatkan ketrampilan dan pemahaman aspek kebudayaan asing bagi tour guide/pemandu wisata dalam memandu para turis/wisatawan asing sehingga tercipta proses guiding yang sopan, santun dan menggunakan bahasa Inggris yang baik dan beretika.

\section{Landasan Teori / Kajian Pus taka}

Pramuwisata adalah profesi di bidang kepariwisataan. Pramuwisata disebut juga Pemandu Wisata atau Tour Guide dalam Bahasa Inggris. Di Indonesia, secara nasional telah dibentuk organisasi yang mewadahi profesi ini, yaitu Himpunan Pramuwisata Indonesia atau HPI. Organisasi ini telah memiliki jaringan ke seluruh provinsi di Indonesia. Di beberapa daerah juga terbentuk sejumlah organisasi serupa yang bersifat lokal.

Menurut Kamus Besar Bahasa Indonesia (KBBI) Pramuwisata adalah petugas pariwisata yg berkewajiban memberi petunjuk dan informasi yg diperlukan wisatawan. Pramuwisata disebut juga Pemandu Wisata atau Guide dalam Bahasa Inggris. Menurut Peraturan Menparpostel RI, Pramuwisata adalah seseorang yang bertugas memberikan bimbingan, penjelasan dan petunjuk tentang obyek wisata serta membantu keperluan wisatawan lainnya. Menurut European Committe For Standardisation, tourist guide is a person who guide visitiors in the language of their choice and interprets the cultural and natural heritage of an area which person normally possesses an area-specific qualification usually issued and/or recognized by the appropriate authority.

Secara umum, seseorang yang hendak menjadi pramuwisata di Indonesia disyaratkan untuk memiliki licence yang diterbitkan oleh HPI. Ketentuan ini terutama bagi pramuwisata yang melayani wisatawan asing agar kualitas pribadi pramuwisata selalu mencerminkan ke- 
Indonesia-an serta menjaga validitas berbagai informasi yang disampaikan kepada wisatawan. Termasuk pula kinerja pramuwisata dalam kaitannya dengan "pihak pemakai" yaitu biro perjalanan wisata yang membawa wisatawan. Pada umumnya, pramuwisata atau tour guide diartikan sebagai setiap orang yang memimpin kelompok yang terorganisir untuk jangka waktu singkat maupun jangka waktu yang panjang. Tugas tour guide memiliki beberapa spesifikasi tergantung dari tugas apa yang sedang dia lakukan (sesuai dengan kemampuannya). Seorang guide khusus di lokasi yang khusus/tertentu disebut local guide yang biasanya menjadi petugas tetap di lokasi tersebut (contoh: Museum, botanical garden, zoo dan lain-lain).

Tata Nuriata (1995:1) pramuwisata berasal dari bahasa Sansekerta yaitu pramu, wis, dan ata. Pramu berarti pelayan atau orang yang melayani, wis berarti tempat dan ata berarti banyak. Pendapat umum mengartikan wisata sebagai keliling atau perjalanan sehingga dalam hal ini pramuwisata dapat dikatakan sebagai petugas yang melayani orang yang sedang melakukan perjalanan wisata.

Oka A. Yoeti, pramuwisata adalah seorang yang memberi penerangan, penjelasan serta petunjuk kepada wisatawan dan traveler lainnya, tentang segala sesuatu yang hendak dilihat dan disaksikan bilamana mereka berkunjung pada suatu objek, tempat atau daerah tertentu.

Prof. E. Amato dari ILO, Guiding Technique menyatakan: "tour guide is a person employed either by the travelers, a travel agency or any others tourist organization, to inform, direct and advice the tourist organization, to inform, direct and advice the tourists before and during their short visits". Pramuwisata adalah seorang yang bekerja untuk wisatawan, biro perjalanan, ataupun lembaga kepariwisataan lain untuk memberikan informasi, memimpin perjalanan atau memberi saran-saran kepada wisatawan sebelum atau selama kunjungan-kunjungan singkatnya.

\section{METODE}

\section{Metode Kegiatan}

Dalam rangka terlaksananya kegiatan ini, peneliti bermitra dengan tim pelaksana yakni dosen Program Studi Pendidikan Bahasa Inggris Fakultas Bahasa dan Seni Universitas Negeri Manado dengan Dinas Pariwisata Kota
Manado dan unsur pramuwisata mandiri lainnya.

\section{Prosedur Pelaksanaan Kegiatan}

Pelaksanaan kegiatan pelatihan terdiri atas 4 (empat) tahap yaitu:

1. Perencanaan

Kegiatan pertama yang dilakukan adalah melaksanakan survey tentang pariwisata di kota Manado. Selain itu, membaca berbagai tulisan tentang kepariwisataan kota Manado baik yang tertuang dalam buku ataupun pada majalah/Koran lokal. Selanjutnya melaksanakan wawancara dengan pihak terkait seperti Dinas Pariwisata dan pramuwisata mandiri. Dari hasil wawancara kemudian dipersiapkan hal-hal teknis pelaksanaan kegiatan, seperti tempat pelaksanaan dan sarana pendukung kegiatan lainnya.

2. Pelaksanaan kegiatan pelatihan

Program Pelatihan Bahasa Inggris bagi Pemandu Wisata dilaksanakan dengan melibatkan para pemandu wisata yang ada di Kota Manado yang berjumlah 16 orang. Kegiatan pelatihan dilaksanakan selama 9 jam yang terdiri dari teori dan praktek. Adapun deskripsi pelaksanaan kegiatan pelatihan sebagai berikut:

a. Pelaksanaan Hari Pertama

Pelaksanaan kegiatan pada hari pertama ini dimulai pada pukul 10.00-13.00 WITA. Materi pelatihan pada hari ini terdiri dari: (1) Penjelasan pelatihan selama kurang lebih $1 \mathrm{jam}$, (2) Materi pelatihan yang berisi tentang basic English for tour guides. pemberian materi ini bertujuan agar para pemandu wisata memahami seluk beluk bahasa Inggris untuk wisatawan asing. Adapun metode pelatihan yang digunakan adalan ceramah, diskusi, dan tanya jawab. Pada hari pertama ini peserta secara aktif berperan serta mengikuti pelatihan. Hal ini ditunjukkan dengan antusiasme peserta dalam menanggapi materi yang berkaitan dengan communicative basic English for tour guides. b. Pelaksanaan Hari Kedua

Agenda program pelatihan pada hari kedua masih berupa pemberian materi berupa teori. Teori umum yang diberikan berhubungan dengan kebudayaan asing secara umum. Teori tentang kebudayaan disampaikan dengan tujuan agar peserta dapat mengerti kebiasaan ataupun ciri khas dari para wisatawan asing. Materi pertama yang disampaikan berjudul "etika dan 
sopan santun dalam berbahasa Inggris bagi pemandu wisata". Materiini bertujuan agar para pemandu wisata memahami tentang etika dan sopan santun ketika menerima dan menuntun para wisatawan. Sementara itu materi kedua berjudul "Seluk-beluk penggunaan bahasa Inggris bagi para wisatawan". Materi ini diberikan bertujuan agar para pemandu wisata mampu menggunakan kata-kata yang baik dan tata bahasa yang sopan ketika berkomunikasi dengan para turis atau wisatawan yang mereka pandu.

c. Pelaksanaan Hari Ketiga

Pelaksanaan kegiatan pada tahapan ini difokuskan pada praktek berbahasa Inggris ketika memandu wisata. Masing-masing peserta pelatihan diberikan kesempatan untuk tampil dan mempraktekkan kemampuan berbahasa Inggris mereka. Selanjutnya, mereka diperkenankan untuk saling mengoreksi dan memberikan masukan satu sama lain. Sampai pada akhirnya dosen dari pihak Program Studi memberikan koreksi yang dapat membantu dan mempermudah peserta dalam berbahasa Inggris.

3. Evaluasi dan refleksi hasil kegiatan

Evaluasi dilaksanakan untuk mengukur kemampuan peserta pelatihan. Dari hasil evaluasi didapatkan bahwa kegiatan seperti ini harus dilaksanakan secara berkelanjutan, sehingga pemahaman para pemandu wisata akan bahasa Inggris, budaya dan kesantunan dalam bertutur ketika melakukan pemanduan senantiasa berkembang. Refleksi penting dilakukan untuk menilai kegunaan dari keseluruhan kegiatan pelatihan yang dilaksanakan. Selain itu, segala kekurangan yang ada selama pelaksanaan kegiatan dapat diketahui untuk disempurnakan pada pelaksanaan kegiatan yang akan dating. Adapun hasil rekomendasi yang penting akan tercipta sesudah refleksi kegiatan dilakukan. Dan, untuk mendapatkan hasil yang evaluasi dan refleksi yang kompleks dan lengkap, maka kegiatan ini melibatkan pihak dinas pariwisata kota dan program studi.

4. Pelaporan hasil kegiatan.

Pelaporan dibuat sebagai tanda bahwa kegiatan sudah selesai dilaksanakan. Selain itu, pelaporan menjadi bukti yang otentik terhadap instansi yang menugaskan. Dalam laporan hasil, juga dilampirkan rekomendasi penting terhadap kegiatan yang sudah dilaksanakan, sehingga pihak pemberi tugas, boleh mengambil langkah-langkah strategis terlebih khusus dalam upaya peningkatan dunia kepariwisataan.

\section{HASIL DAN PEMBAHASAN}

Pelaksanaan kegiatan pelatihan ini bertujuan untuk meningkatkan kemampuan berbahasa Inggris para pemandu wisata yang ada di kota Manado. Selain itu, pelatihan ini juga akan membekali peserta dengan teori kebudayaan yang mana dapat berpengaruh besar terhadap sifat kesopan-santunan dalam menjalankan fungsi sebagai tour guide.

Selama tiga hari (11-13), para peserta digodok dengan beragam cara agar boleh memahami bahasa Inggris yang sesuai dalam dunia kepariwisataan. Beragam kegiatan yang dapat menumbuh-kembangkan keaktifan peserta dibuat oleh tim dosen agar kegiatan senantiasa menarik dan tidak membosankan.

Adapun gambaran umum pembahasan kegiatan dapat dilihat pada tabel:

\begin{tabular}{|c|c|c|}
\hline $\begin{array}{l}\text { KONDISI DI } \\
\text { LAPANGAN }\end{array}$ & PELATIHAN & HASIL/TUJUAN \\
\hline $\begin{array}{l}\text { 1.Kemampuan } \\
\text { berbahasa } \\
\text { Inggris } \\
\text { pemandu } \\
\text { wisata di kota } \\
\text { Manado, } \\
\text { secara umum } \\
\text { masih cukup. } \\
\text { 2.Pemahaman } \\
\text { aspek budaya } \\
\text { asing para } \\
\text { pemandu } \\
\text { wisata di kota } \\
\text { Manado } \\
\text { masih minim, } \\
\text { sehingga } \\
\text { berpengaruh } \\
\text { pada } \\
\text { pemilihan } \\
\text { bahasa } \\
\text { Inggris yang } \\
\text { digunakan } \\
\text { dalam } \\
\text { kegiatan } \\
\text { memandu } \\
\text { wisata. }\end{array}$ & $\begin{array}{l}\text { 1.Dilaksanakan } \\
\text { oleh dosen } \\
\text { Unima yang } \\
\text { tersertifikasi } \\
\text { dan } \\
\text { professional. } \\
\text { 2.Didukung } \\
\text { oleh dinas } \\
\text { terkait, yakni } \\
\text { Dinas } \\
\text { Pariwisata } \\
\text { Kota Manado. } \\
\text { 3. Kegiatan ini } \\
\text { didukung } \\
\text { sepenuhnya } \\
\text { oleh para } \\
\text { pemandu } \\
\text { wisata yang } \\
\text { ingin } \\
\text { berkembang } \\
\text { dan } \\
\text { menggeluti } \\
\text { dunia } \\
\text { kepariwisataa } \\
\text { n secara total. }\end{array}$ & $\begin{array}{l}\text { 1.Peningkatan } \\
\text { kemampuan } \\
\text { berbahasa } \\
\text { Inggris } \\
\text { pemandu wisata } \\
\text { di kota Manado. } \\
\text { 2.Pemahaman } \\
\text { budaya asing } \\
\text { dan mampu } \\
\text { menggunakan } \\
\text { bahasa Inggris } \\
\text { yang sesuai } \\
\text { dengan etika } \\
\text { dan tata-krama } \\
\text { yang ada. }\end{array}$ \\
\hline
\end{tabular}

Dengan demikian dapat disimpulkan bahwa kegiatan ini sangat membantu para pemandu wisata dalam menjalankan tugas mereka. Keseluruhan rangkuman hasil kegiatan dapat dipaparkan sebagai berikut:

1. Respon yang sangat positif dari peserta kegiatan. 
2. Peserta mengikuti dan memaknai seluruh proses kegiatan dengan baik.

3. Peserta termotivasi untuk tetap bergelut di dunia kepariwisataan.

4. Dinas terkait mendukung kegiatan secara total.

5. Para peserta mengakui bahwa kegiatan sangat membantu mereka dalam proses pekerjaan mereka, serta mereka menginginkan kegiatan seperti ini untuk dilakukan secara rutin.

6. Peserta dan dinas terkait menyatakan terima kasih kepada pihak pelaksana.

Berdasarkan paparan di atas, maka dikemukankan hal-hal sebagai berikut:

1. Pelatihan bahasa Inggris bagi pemandu wisata sebagaimana yang sudah dilaksanakan di kota Manado, dapat meningkatkan kemampuan berbahasa Inggris, sehingga dapat berpengaruh baik terhadap pelaksanaan kegiatan kepariwisataan.

2. Kerjasama pihak terkait yakni Prodi Pendidikan Bahasa Inggris, Dinas Pariwisata Kota Manado, dan pemandu wisata itu sendiri, perlu ditingkatkan guna menunjang faktor kepariwisataan secara khusus di kota Manado002EX

\section{KESIMPULAN}

1. Kesimpulan

a. Kegiatan pengabdian masyarakat dalam bentuk pelatihan bahasa Inggris pemandu wisata di kota Manado telah terlaksana sesuai dengan rencana dan boleh mencapai tujuan yang diinginkan.

b. Kegiatan pelatihan ini sesuai dengan agenda kerja Dinas Pariwisata Kota Manado dan mendapat dukungan sepenuhnya dari Pemerintah Kota Manado.

c. Kegiatan ini didukung sepenuhnya oleh para pemandu wisata yang ada di kota Manado.

d. Kegiatan ini berkontribusi positif bagi Lembaga Pengabdian Masyarakat UNIMA, terlebih khusus dalam menetapkan program strategis ke depan.

2. Saran

a. Kegiatan Pelatihan Bahasa Inggris Pemandu Wisata di Kota Manado perlu dilakukan secara berkelanjutan.

b. Kegiatan seperti ini dapat dilaksanakan di tempat yang berbeda, guna meningkatkan gairah pariwisata di daerah lain di Indonesia. c. Pemerintah daerah harus mendukung atau melaksanakan kegiatan serupa demi meningkatan dunia pariwisata.

d. Pihak LPM UNIMA perlu mengambil langkah strategis dengan pembiayaan kegiatan serupa di waktu yang akan dating.

\section{REFERENSI}

Hutchinson, T. \& A. Waters. 1987. English for Specific Purposes: A learning-centered approach. Cambridge: Cambridge University Press.

Wurzburger, Rebecca; et al. 2009. Creative Tourism: A Global Conversation: How to Provide Unique Creative Experiences for Travelers Worldwide: As Presented at the 2008 Santa Fe \& UNESCO International Conference on Creative Tourism in Santa $\mathrm{Fe}$, New Mexico, USA. Santa Fe: Sunstone Press. ISBN 978-0-86534-724-3.

Ziger, Irena. 2012. English in Tourism, Cultural Treasure Hunt. Croatia: The National and University Library in Zagreb. 


\title{
PELATIHAN DESAIN PRODUK DAN TEKNOLOGI INDUSTRI KERAJINAN ANYAMAN ECENG GONDOK
}

\author{
Daud Elias Pangkey \\ Fakultas Bahasa dan Seni, Universitas Negeri Manado
}

\begin{abstract}
Pengabdian masyarakat ini sesungguhnya berorientasi pada upaya memberdayakan kelompok masyarakat pengrajin, khususnya dalam pengembangan desain produk yang sesuai kebutuhan pasar/ konsumen dengan tetap memperhatikan kualitas produk melalui pendekatan teknologi industri. Dengan demikian diharapkan ada peningkatan taraf ekonomi/kesejahteraan masyarakat pengrajin di pedesaan melalui pendekatan IPTEKS, sesuai amanat Tridarma Perguruan Tinggi. Untuk mencapai tujuan tersebut ditempuh melalui metode pembelajaran andragogik yang lebih menekankan pada pelatihan teknis (praktek), mulaidari keterampilan desain produk, teknis produksi secara industrial sampai pada sistem manajemen pemasaran produk. Program pengabdian masyarakat ini telah membantu para pengrajin baik dalampengadaan bahan bakuanyaman beserta asesorisnya maupun sejumlah peralatan penunjang teknologi produksi/ industri, sehingga desain produk yang ditawarkan dapat terwujud sesuai harapan, berkualitas dan berciri khas serta dapat bersaing di pasaran.

Target yang telah dilaksanakan melalui program ini meliputi : (1) pengadaan bahan baku berupa tangkai eceng gondok, kain pelapis, rets, tali/ sabut gantungan, pita-pita dan asesoris penunjang keindahan produk anyaman, (2) pengadaan peralatan, mesin jahit dll, (3) prosespengolahan bahan, pengenalan desain produk sampai pada proses produksi anyaman beragam desain produk berupa tas, dompet dsj yang modis serta trendy (seperti yang tampak pada dokumen fisual berupa foto-foto terlampir).
\end{abstract}

Keywords: Desain Produk, Teknologi Industri, Kerajinan Anyaman. 